\title{
THE NOTION OF THE "THREE HILL COUNTRY" IN THE ANCIENT EGYPTIAN CIVILIZATION
}

\author{
Elsharnouby, R. \\ Lecturer, Guidance dept., High Institute of Tourism and Hotels-Abu-Keer, Alexandria, Egypt.
}

Received 22/6/2013

E-mail: relsharnouby@hotmail.com

Accepted 12/12/2013

\begin{abstract}
The ancient times witnessed no deserts as the vast deserts were once agricultural territories enriched by water of the heavy rains. By the Pharaonic Periods, the Nile Valley was restricted between two barren plateaus; these deserts were formed of several hilly chains of sands traversed by valleys linking between the Nile and the deserts. These hilly chains were represented on the Egyptian monuments and its accompanying texts by the sign 2 hist which is the origin of our main concern. The research deals with the significance of the h3st sign such as the deserts, the foreign countries the necropolis; and its various ways of

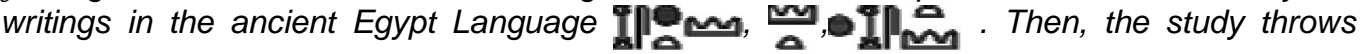
some light on the types of land referred to as $h 3 s t$ such as the mountainous land, the foreign countries surrounding the Egyptian land and the deserts. It also focuses on the names of the geographical divisions determined with the $m$ hisst sign

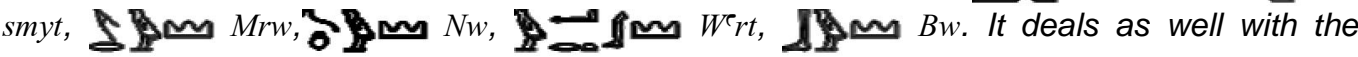
names of the Egyptian provinces and regions determined with the Sign hist such as:

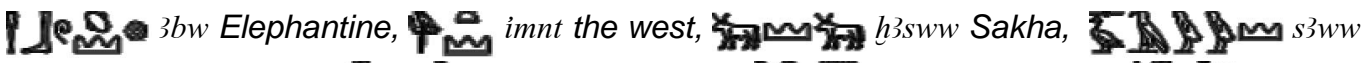

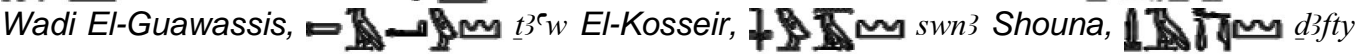
Safa, G] whit The Oases, etc... Then the research focuses on the notion of the "three hill country" in the ancient Egyptian texts through the different historical phases indicating the various significances meant by the determinative 1 hsst:- the determinative of the eastern and western mountains, the determinative of the necropolis and the determinative of the foreign countries. It also studies the titles related to the term $m$ hist: either titles related to the foreign countries or the deserts. Finally, the study ends by the scenes and monuments related to the sign sign as the Gods Spd, Ha and Min.
\end{abstract}

Keywords: h3st, deserts, foreign countries, hills, Old Kingdom, Middle Kingdom, New Kingdom, land.

\section{Introduction}

The ancient times witnessed no deserts as the vast deserts were once an agricultural territories enriched by the water of the heavy rains, of which traces of plains could be visible till now in the Egyptian deserts. Then, these places faced great climatic changes that led to the desertification of the lands [1]. By the 
Pharaonic Periods, the Nile Valley was restricted between two barren plateaus; these deserts were formed of several hilly chains of sands traversed by valleys linking between the Nile and the deserts. Nowadays, the Egyptian farmers are linked to their fields located in the vicinity of the Nile Valley that could be reached through numerous sandy ups and downs. These farmers (fillah) as soon as they traverse their agricultural line of land, they consider themselves in the deserts depicted in their minds as the mountain (el-gabal). The mountain which was the same idea thought by their ancient Egyptian predecessors who represented the sandy hilly ups and downs for (el-gabal) or the mountain on the Egyptian monuments and its accompanying texts by the sign $M$, which is the origin of our main concern in the following pages (the three hill country) sign that had a variety of significances for the ancient Egyptians determining the necropolis, the deserts, the mines, the quarries and the foreign countries [2].

\section{The Significance of the h3st Sign}

This hieroglyphic sign, fig. (1) appeared in the ancient Egyptian texts and inscriptions representing the hilly areas outside the Nile Valley: vast distances including the deserts and semi desert regions surrounding the valley as well as any foreign land. The three hills of the sign adapted the signifying colors (yellow-pink and reddish) of the deserts and the sandy terrains with scattered darker spots indicating the roughness of the area. The $\leadsto$ hist sign was used in most of its aspects to refer to both the geographical point of view and the cultural interaction with the foreigners [3]. From the ancient Egyptian point of view, it is hypothetically assumed that the h3st sign was the contrary of the sign $=t 3$ "the land" [4] that is on the other side indicated the green line running along the bottom, illustrating the cultivated land of the Nile Valley. Thus, the hist sign is a mixture of naturalistic image and graphic convention: the idea of asperity of the earth and its sandy, rocky nature that also characterizes the natural depiction of the desert regions within the numerous hunting scenes decorating the Egyptian tombs and temples. Moreover, being on the borders was a source of danger emphasized by the invasion of nomads attacking Egypt to benefit from the stable life on the boundaries of the River Nile. These nomads formed one of the dangers that threatened the Egyptians because of their usual and repeated attempts to penetrate the Egyptian territories because of the bad conditions of their countries that led to a great difficulty of living due to the increasing aridity (that started in the remote Pliocene Era and ended in the Third Millennium BC) that was linguistically and scenery expressed by the three barren hill country sign ${ }^{\sim}$ hst [3]. Thus, the term is closely connected with the arid, barren desert of which the main aspect was the sands that perhaps can be explained by the usage of the term $h 3 s t$ as a related phrase with the vocabulary indicating sands $\stackrel{\sim}{\perp}[\subset] \stackrel{\square}{\square}$ h3st $\check{s}\ulcorner\dot{i}$ signifying the sandy desert as a land or an inhabited region [5].

Figure (1) the h3st sign (After Smith, 1949, p. 379, plate B.) 


\section{The hist Sign in the Ancient Egyptian Language}

The word ${ }^{3} 3 s t$ was written in various ways as during the Old Kingdom [5], then became $\triangle$ by the Middle Kingdom [7], and then $1=$ and $f_{0} \sim$ in the New Kingdom [5]. The term was attested in other variants such as $\sim$ since the Old Kingdom to be read as hist referring to the foreign countries or the desert. Sometimes read as smyt indicating the desert and the hilly lands which was also written as $\_1,\llcorner$, $\sim$ [5]. Moreover, Gauthier mentioned that the term that was used to indicate the mountainous foreign countries, the desert, the deserted provinces and the necropolis [7]. Brugsch supposed that the word h3st is derived from the verb fla hl $3 s$ meaning to escape, to run away, or to be saved of a danger [8]. Meeks defined the term 잉 as the hills flanking the Nile Valley that were naturally cultivated then they were deserted due to the climatic changes to be complete deserts [9]. However, Gauthier refused these ideas

\section{Types of Lands Referred to as h3st}

The term hist appeared usually with both the determinatives and [5] that was hypothetically applied on three kinds of lands as follows: 1- The mountainous lands as a contrary for the

flat fertile land $=t 3$ that may explain the reason why it was written with three hills or mountains. Most probably as an indication for the mountainous inflated lands [10]. 2- The h3st lands as the foreign countries surrounding the stating that the word h3st is a name applied in general for all the foreign countries in addition to the deserts and the provinces on the desert edge as what will be explained in the following pages. It is well attested that referred to the deserts surrounding Memphis on which the great pyramids are built [10]. As a general expression, h3st was used to express the foreign countries as hist w3it expressing the far countries, h3swt mhtiw referring to the northern countries and ḩsswt šm ${ }^{`} w$ mhtiw indicating both the northern and southern countries [10]. The dual form of the word was flo histy means the two foreign regions (outside the Egyptian proper borders) that was referred to by Brugsch as foreign countries depending on the ancient Egyptian texts that applied the word on the lands located outside their borders. Thus, it is considered to be foreign lands. Finally, the plural form of the word $h 3 s w t$ varied as it was written as

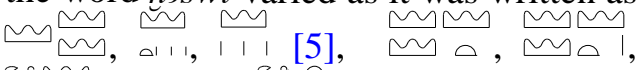

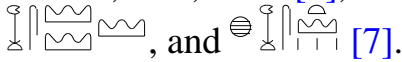

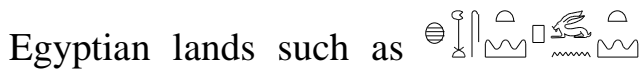
hist pwnt "the land of Punt" recorded on the walls of the temple of Hatshepsut. 3- The h3st lands as deserts; the term was sometimes used to indicate the deserts in general [5] that are evidenced in the description of Amun-Rê as "Amun-Rê Master of Deserts" the title occurred in an inscription of Ramses IV at Wadi Hamamat [11].

\section{Names of the Geographical Divisions Determined with the Sign $h 3 s t$}

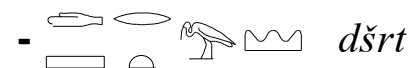

The denomination, that was applied to the deserts since the Old Kingdom, was $\rightleftarrows 0$ be $\leftrightarrows \subset$ during the Middle
Kingdom, then it was written as by the New Kingdom (Eighteenth Dynasty) and, finally, 
and $\stackrel{\ominus}{\circ}$ during the Greco-Roman Period [5]. The term was translated by Faulkner [12], as the red land referring to the red color indicating the extreme barren nature of the deserts with the reflection of the sun rays and temperature on the yellow sands giving the red color [13]. Also, it was

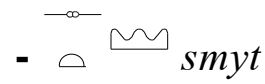

This term; indicating the foreign countries, the deserts and the necropolis; attested in the Egyptian texts was written in different variants as $-\infty$ A $\sim$ during the Old Kingdom, then ${ }^{-\infty} \sim$ by the Middle Kingdom that was changed twice during the New Kingdom as the texts of the New Kingdom (Eighteenth Dynasty) recorded the term as . Whereas, the Amarna period texts mentioned the smyt as FAt [5] and finally $\sim, \infty$, during the Late Period. The term was written in the plural form as:-

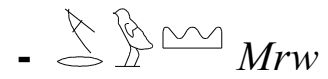

One of the terms that was applied to the adjacent barren regions since the New Kingdom. It was written as $m r w$ during the Eighteenth Dynasty [14], by the New Kingdom and and in the Late Period [5]. Moreover, the pronunciation mrw continued in the Coptic language [15]. The term was used in the Egyptian language to indicate the desert and the

$-8 \Leftrightarrow M N w$

The deserts were known as $n w$ in the ancient Egyptian language as it appeared since the Old Kingdom in the pyramid texts $\&$, in addition to 8,2 . It refers also to

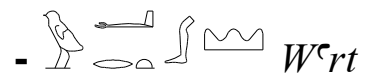

explained by Gauthier as the black yellowish lands referring to the deserts flanking the River Nile including the rocky, sandy and barren lands. Moreover, he mentioned that the term $d \check{s} r t$ is a contrary of the term "kmt" or the black fertile land of Egypt [7].

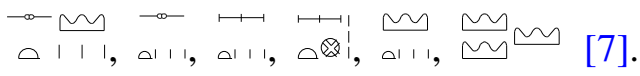
The term smyt was meant in one of its aspects to indicate the place of the wild animals or the mines [5]. The word smyt appeared either with the determinative $\backsim$ referring to the three hill country on the edge of the cultivated land and the town hieroglyph or the two crossed streets [4] perhaps to indicate the exploitation of these sandy hills surrounding the Egyptian lands, the establishment of a living town for the workers of mines, or the planning of the necropolis taking the form of a town for the deceased.

bad conditioned living regions; the places where the wild animals live (deserts in a metaphoric reference) [5]. However, it was stated by Faulkner that the term $m r w$ signifies the adjacent coastal regions, port and sea shores [12]. The term was written usually with the determinative three hill country sign $h 3 s t \stackrel{M}{m}$ or the avenue with trees $w 3 t^{\frac{n}{2}}[4]$.

the hunting zones [5] in the deserts (that is emphasized by the hunting stick in the written hieroglyph of the word, used in the wild animals hunting activities) [16]. 
Faulkner stated that the word was meant to indicate the deserts, in addition to the desert hill bases. The term was usually written with the determinatives $\rightleftharpoons$ and $\rightleftharpoons$ [12].

- $\int B m B w$

The word signifies the place, but in some cases it was written with the
During the Old and the Middle Kingdom the word $W^{\top} r t$ referred to the necropolis and it was written as and $\ \rightleftharpoons$ [5].

determinative $\stackrel{m}{m}$ to indicate the desert [12].

\section{Names of the Egyptian Provinces and Regions Determined with the Sign $h 3 s t$}

\section{- $\int 3 b w$ Elephantine}

One of the Nile islands at the northern end of the First Cataract that

- $\backsim$ imnt the west

The Third Nome of Lower Egypt [18], it extended along the western boundary of the Canopic Nile for about 147, $523 \mathrm{~km}$ [19]. This Nome existed since the early Pre-Dynastic Period [17].

was referred to by the Greek and Latin geographers as the Libyan province due to its borders with the western desert [20].

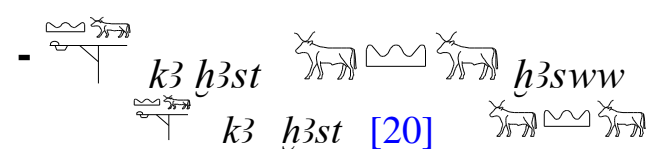
h3sww Sakha [18], the sixth Nome of Lower Egypt, current Sakha about some

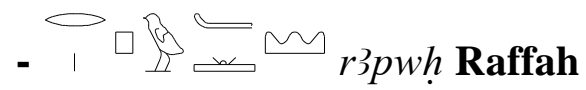

The city is located along the Mediterranean between Egypt and Palestine about $45 \mathrm{~km}$ to the east of El-

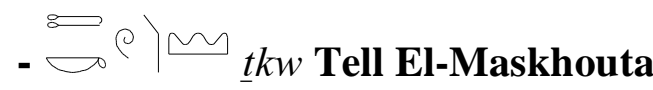
The capital of the Eighth Nome of Lower Egypt, located on the site of ancient (Beithoum). Now, it is cons-

- ${ }^{3}$ rw El-Kantara

According to Gauthier 1925-1931

[7] It was the capital of the Fourteenth

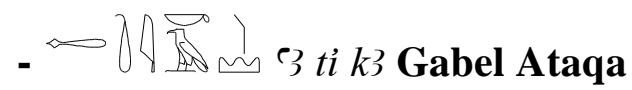

Gauthier has mentioned a mountainous region to the east of Egypt

\section{Sakha}

kilometers to the south of Kafr ElSheikh governorate [21].

Areish, on the eastern borders of Egyptian land [22].

idered as a village in El-Esmaeliya governorate.

Nome of Lower Egypt called "hnt ỉbt" [23].

between the Red Sea and the land that must have been named Gabel Ataqa [7].

- $\bar{z}^{-\infty}$ \& $s w w$ Wadi El-Guawassis 
One of the Red Sea ports near Safaga about $7 \mathrm{~km}$ away from the Red

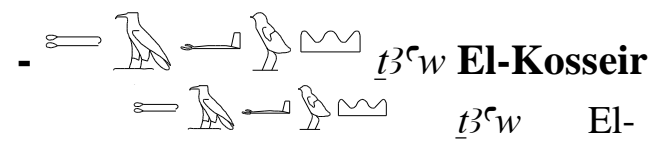

Kosseir, it is a port which is considered

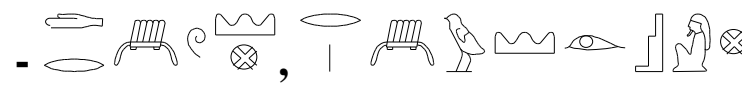

The site is located about some kilometers south eastern Cairo, it represented for most of the historical

${ }_{-} \quad$ Pr ḩ nb imnty Berenbal

A site located on the Lake Brollous nearby Menyet El-Morshed

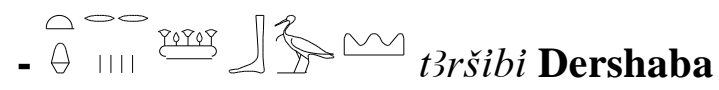

One of the ancient villages in Gharbiya governorate. It was mentioned by Gauthier as a site in

- F 1 . M swn Shouna

The site was stated to be located in the Monofiya governorate or it represented the ancient name of $\mathrm{Sa}$

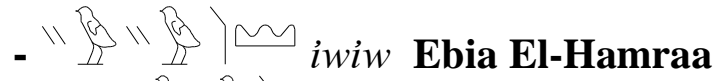

"Q

Hamraa, a name of one of an ancient

- 2$]$

The name was stated addressing a site separating between the Libyan Desert and Wadi EL-

- $\Rightarrow$ A

One of the ancient villages at Kom Hamada mentioned several times in the ancient Egyptian and the Coptic

- $\sqrt[\square]{\sim}$ ibhit Ebheet El-Haguar

Gauthier mentioned this name as

- d J d J
Sea coast. It existed at least since the Old Kingdom [24].

one of the most ancient ports on the Red Sea [25].

$d r 3 w, r 33 w$ wsir Tora

periods the source of the fine limestone that was used in the great constructional works [21]. about $65 \mathrm{~km}$ to the north of "Kafr ElSheikh" governorate [18].

Syria or Palestine. The name of the site was stated to be a part of the Egyptian land nearby Fowa [7].

El-Hagar [18]. The name was mentioned by Gauthier as a site in Palestine [7].

village at EL-Dalanguat [7] that lies in the northern western part of Egypt.

Natrun. Thus, the site is one of the ancient villages belonging to Beheira governorate [18].

texts as one of the Lower Egyptian villages [18].

represents a non specific region either in Asia or in Africa [7]. 
U. of the ancient villages that belonging

- $\frac{\sum}{\stackrel{2}{\sim}} m r$ Meir

Gauthier has mentioned a locality called Moirai or Moirou stating that it was in the nearby of Manfalout located on the western boundary of the Nile about $15 \mathrm{~km}$ to Assiute governorate at the present time [7].

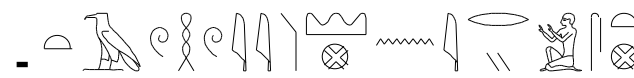
An ancient village called originally Iris then it became Paris. It was mentioned by Gauthier as

\section{- $8 f m h n m t-{ }^{\circ} n t$ The Necropolis}

The term was used to indicate the necropolis in the New Kingdom texts, especially in the texts of Deir El-

\section{- $\underline{\text { h }} r t$-ntr The Necropolis}

The sign $\stackrel{M}{\longrightarrow}$ used to determine different words related to the west and the necropolis of which the term 进我 hrt-ntr as - $f_{\ominus}^{m} \overline{\bar{\Xi}}$ c $n h t 3 w y$ The Life of the Two Lands

The name applied to one of the districts of ancient Memphis. Kitchen, mentioned that outside the white wall district (the ancient name of Memphis) at the very beginning of its history there was "`nh t3wy" [28] where a number of funerary temples for a number of on. north of Assiout including the necropolis of the rulers of the Fourteenth Upper Egyptian Nome in the Old and the Middle Kingdom [26].

\section{t3 whwy n irys Paris}

Tkhonenyris stating the position nearby the Kharga Oasis [7].

Medinah that will be explained later

im $3 h w$ hr wsir nb krs $m$ hrt-ntr revered with Osiris the lord of burial in the necropolis [27].

\section{- h8]}

The ancient Egyptians applied the term $\backsim$ wht for the oasis that gives almost the same pronunciation for the modern Arabic word Waha [5].

$-\theta^{\circ} M$ htiw Sinai

Meaning the scales [5] as the peninsula was connected with the scales of turquoise to the extent of applying the term $m f k 3 t$ successive kings starting from Amenhotep III till Ramses II extend. It was mentioned that this part is closely connected to the western part of the city in an earlier period. However, it is difficult to determine the proper site of this part of the city [29].

Gauthier stated that 8 al was linguistically used as a general term for the oases of the western desert and not any specific oasis [7].

written as $\backsim$ in the Old Kingdom, W by the Middle Kingdom on Wadi Maghara at Sinai which is the 
same denomination of the turquoise in the ancient Egyptian language.

\section{The Notion of "Three hill country" in the Ancient Egyptian Texts through the Different Historical Phases \\ This part of the study concerns indicating the various significances mainly of the different textual examples meant by the determinative $\stackrel{\sim}{\sim} 3 s t$}

\subsection{The determinative of the eastern and western mountains}

7.1.1. The coffin texts

Spell 404

(The arrival at the first portal of the field of Rushes)

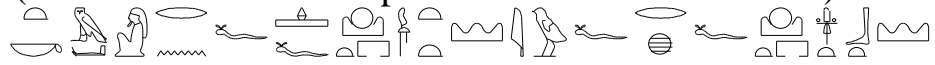

tkm rn.f htp.f(m) 3ht imntt iw.f rh.f 3 ht i $3 b t t$

"He (the gate-keeper) opens up the western horizon, he knows the eastern horizon, and his name is "Tkm" [31].

\section{Spell 818}

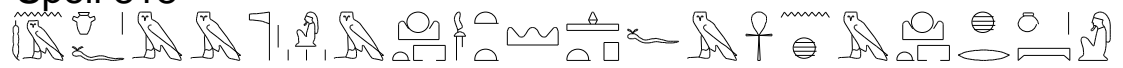

$n d m$ ib.f $m m$ ntrw $m$ 3ht imntt htp.f $m$ ' $n h$ $m$ 3ht hr $n w$

"He is happy among the gods in the western horizon, (and) he sets in life in the horizon with $\mathrm{Nu}$ ".

7.1.2. The book of the dead

Chapter 17

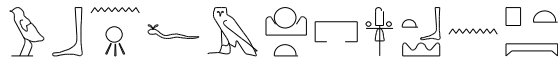

\section{Wbn.f $m$ 3ht isbt nt pt}

"he (Rê) rises in the eastern horizon of the sky [32].

7.1.3. Stela of ( $h r m ~ h b)$ in the British museum (N. 551)

Both the eastern and the western horizons were mentioned in the context of this stele as:

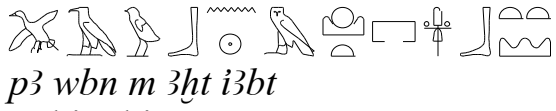

"This shines in the eastern horizon" [33].

\subsection{The determinative of the necropolis}

7.2.1. A text from the temple of Deir El-Medinah reads

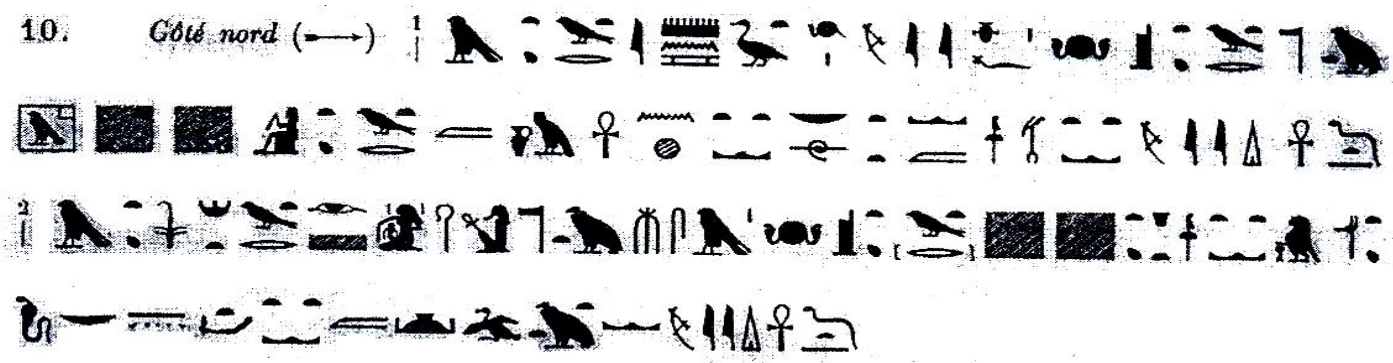

Bikt wrt mryt imn s3t $r^{\ulcorner}$mry ib.f nsyt bit 3st wrt mwt ntr ḥt-hrr .... špst wrt $m$ hnnm `nht nbt styt m imntt w3st mryt di ${ }^{\mathrm{n}} \mathrm{n} \underline{\mathrm{d}} \mathrm{d} t$.

Bikt hmt nsyt wrt ir .. rr hk $\mathrm{k} 3$ mwt ntr ms hr nsyt-bit 3st wrt .... hnwt imntt špst wsrt nbt

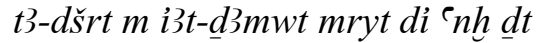

"The great falcon, beloved of Amun, the daughter of Rê, beloved of his heart. The queen of the south and the north, Isis the great, the mother of the god, Hathor..... The honored in the necropolis, the mistress of the necropolis 
to the west of Thebes, the beloved to be given life forever". "The falcon, the great royal wife who ..., suckles the ruler, the mother of the god who gave birth to Horus. The queen of the south and the north, Isis the great......mistress of the west, the strong, mistress of the necropolis in the "Djamut" the beloved one, to be given life forever".

- Comment

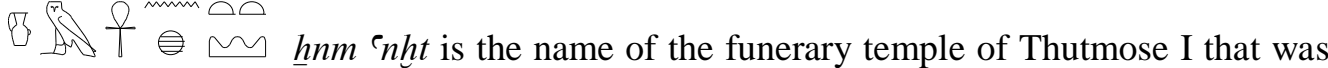
extended afterwards to contain the necropolises of the western border [34]. Gauthier stated that this expression meant (the hilly region united with life), that refers to the southern part of the Theban Necropolis including the Ramesseum, Deir El-Medinah and Medinet Habu. Then it was used as one unit addressing the necropolis in general [7].

7.2.2. In the recitations and prayers for the god in the Middle kingdom Pap. Louver C30

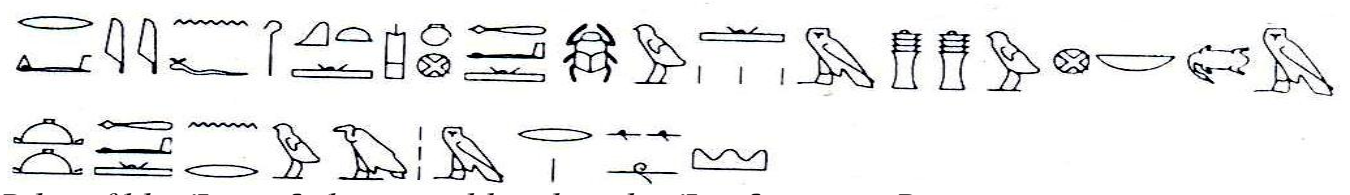

Rdy n.f hkjt'Iwnw 3 hprw $m$ d ddw nb snd m 'B3ty 3 nrw m R3-st3w

"The one who is given the rule of 'Iwnw (Heliopolis), the great of appearances at $\underline{d} d w$ (Abu Sir), master of freight in 'T3ty

\subsection{The determinative of the deserts}

The sign $\stackrel{m}{\longrightarrow} s t$ referred to the vast deserts flanking the narrow strip of the Nile Valley that was evidenced

\subsubsection{The sphinx stele of Amenhotep II}

, the powerful in $R 3-s t 3 w$ (The Necropolis)" [35].

through some textual evidences as follows:

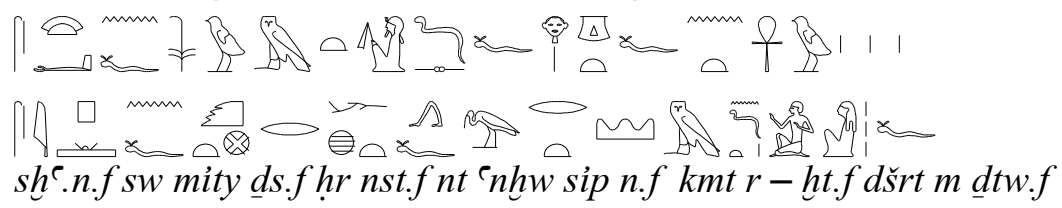

"He (the god Amun), made him throne of the life giving him Egypt and (the king) appear like himself on his the desert with its people" [33]

\section{- Comment}

Here, the sign $\longrightarrow$ appeared as a determinative in the word $d \check{s} r t$ that was used to signify the desert lands. Therefore, the role of the three hill country sign is apparent in ensuring the sandy nature of the regions in which it was used as determinative.

\subsection{The determinative of the foreign countries:}

The hieroglyphic sign $M$ appeared in different textual evidences

7.4.1. A text from the reign of Thutmose III stating the great power of this great warrior

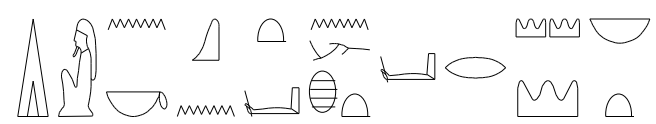

di.i n.k knt nht $r$ ḩswt nbt

"I gave you the victorious power over all the foreign countries" [33] 
- Comment

Here, the vanquished $h 3 s w t$ foreign lands were mentioned as being conquered by the powerful pharaoh who was supported by the gods giving him $k n$ that was used to indicate the materialistic power that leads usually to the victories [36].

7.4.2. Ramses II was mentioned as the conqueror of the foreign lands in a text reading

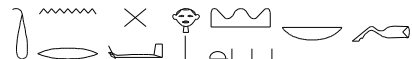

tnr hr h3swt nbt nb hpš

"the seizer king of all the foreign countries, master of power" [5].

7.4.3. The foreign countries were mentioned as hist in another text dated to the reign of Ramses III

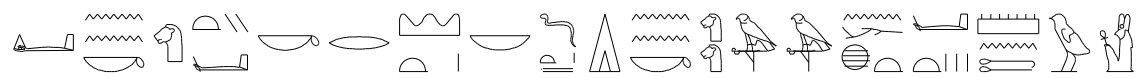

di.n.(i) n.kphty.k $r$ h $3 s t n b(t) \underline{d t}$ di.n.(i) n.k phty nbwy nhtw mntw

"Amun says "I gave you your power against any foreign country forever; I gave you all the power and victories of Montu".

- Comment

The text here indicated the Egyptian control over all the foreign countries using the word phty that means human strength, the word that was used in the titles of several gods and kings referring to their power. The text here states the victories of Ramses III in all the foreign countries as he was given the power of the gods against them forever.

\section{Titles Related to the Term \\ 8.1. Titles related to the foreign countries}

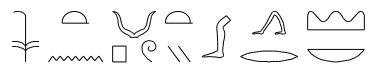

wpwty nsw r h3st nbt:

"The messengers of the king to all the foreign countries", this title might have been held by the ambassadors of the Egyptian Kingdom to the adjacent foreign countries with whom Egypt had any kind of relationship [37].

Des $m \frac{m a}{2+1}$

imy-r h3swt nbt

"The overseer of all the deserts and the foreign countries" that was held by some Egyptian employees [5].

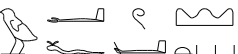

wef h3swt [5].

"The one who subdues the foreign nations", this title appeared in the New Kingdom texts describing some great conqueror kings such as Ramses II [12].

(9) $m$

hr h3swt

"The one who is over the foreign countries", a title that was repeated many times concerning the relationship with the foreign countries [5].

$m^{x}$

hr ḩ hist.f

"The one who is over his desert (The foreign country)" that was used with some metals such as gold, silver and copper which were mainly extracted either from the 
mines of the deserts or imported from some neighboring countries such as the gold of Nubia that was recorded as $91,1, l^{*} n w b$ h h h 3 st.f "The gold over his desert" [5].

nb hist

"Master of the foreign countries". It was one of the titles of Amun-Rê the official god of ancient Egypt.

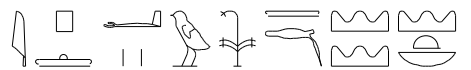

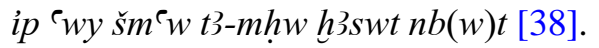

"The under-supervisor of the treasury who assesses the production of Upper and Lower Egypt and all the foreign lands". [39].

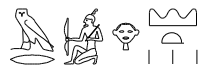

imy-r mš hr ḩ3swt

"The general of the army in the desert", the person whose responsibility was to safeguard the frontier and the security of the mining expeditions sent to the desert [40]. The title was held by one of the Nobles of the Middle Kingdom during the reign of Montuhotep IV [41].

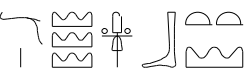

imy-r h3swt 'T3btt

"Overseer of the eastern desert", the title was held by some of the Middle Kingdom Nobles indicating the importance of the eastern desert by the time of the Middle Kingdom [42].

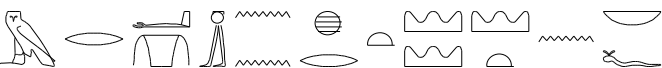

imy-r3 ' $($ w) inn hrt ḩ3swt $n$ nb. $f$ [33].

"Overseer of the foreign mercenaries" (most probably the Egyptian Nubians), who brings the products of the foreign lands to his lord [27].

\subsection{Titles related to the deserts}

$m-m M$

imy-r ${ }^{\ulcorner}(w y)$ smiwt $n b(w t)$ [33].

"The overseer of the stock of production (products) of every desert region" [27].

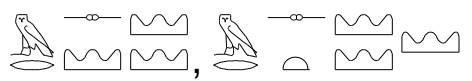

imy-r3 smiwt

"Overseer of the deserts or the desert regions" [27].

$\stackrel{\sim}{\sim} m \mathrm{P}^{\infty}$

imy-r smiwt imntt

"Overseer of the western desert" [27].

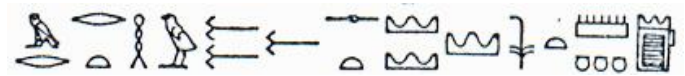

Imy $-r$ r rthw smiwt mnnw nswt

"Overseer of the desert blockhouses and royal fortresses who had the alternative title"

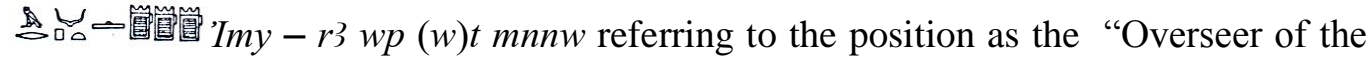
affairs of the fortresses" [40].

$m \Leftrightarrow \infty v^{\infty}$

imy $-r^{3}$ tst nt smit 
"Overseer of the herd of the desert [27]. In addition to some other administrative titles related to the protection of the deserts and the desert regions were recorded in the Egyptian texts such as 11 imy - r3 smit, "The overseer of the desert",

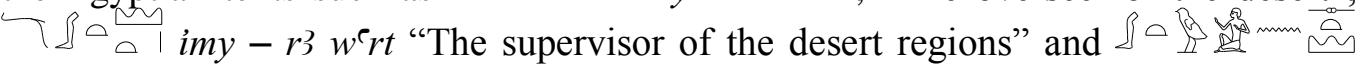
$w^{\text {r }}$ rtw $n$ smit "The manager of the desert regions" [7].

\section{Scenes and Monuments Related to the Sign $h 3 s t$}

\subsection{The sign h3st on the early dynastic monuments}

A fragmented ivory label of the time of King Den representing the king standing with staff and mace. He is wearing an Early Dynastic garment style (most probably of military nature) and a long wig. The standing pose facing the right combined with the mace head and the inscriptions reading

h3styw could prove the idea of striking the eastern foreign countries that was evidenced by other related monuments dated to the reign of the same king, fig. (2) [43].

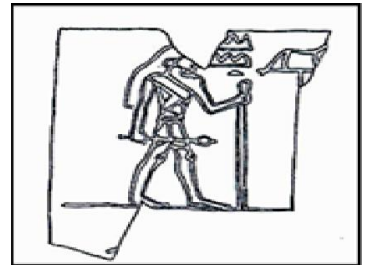

Figure (2) king Den facing the east (the eastern foreign countries) (After Smith, 1949, p. 120, fig.36)

\subsection{The sign h3st on the fragmented relief of king Khasekhem}

The lower register of the fragmented inscription of King Khasekhem, fig. (3), discovered by Quibell at Hierakonpolis [44], is decorated by the srh of the King Khasekhem surmounted by the Hawk Horus and a group of hieroglyphs tbt $3 h t \quad r$ hjst "The excellent sandal against the foreign countries". This phrase explained another attitude of crushing the foreign countries under the feet of the king replaced in this case by his sandal in a metaphoric representation [45]. forming an inscription reading:

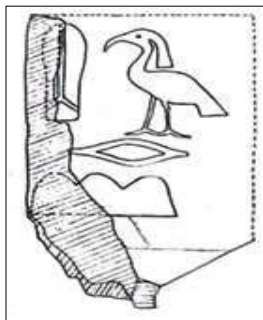

Figure (3) the lower part of the fragmented relief of Khasekhem (After Godron, 1968"A propos d' Une Inscription de L'Horus Khasekhem", Cde XLIII, Bruxelles, p. 34)

\subsection{The sign hist on the scarabs of the Hyksos rulers}

The sign h3st was mainly connected as it was previously indicated in the titles and records of the Hyksos rulers who were usually described

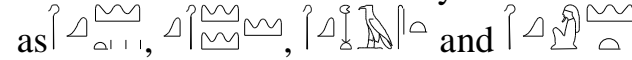
$h k 3$ h 3 swt "the foreign rulers of the foreign countries'[5]. Our example is one of these records on the scarabs commemorating the Hyksos Period in Egypt inscribed by the names of these foreign rulers who were not accepted by the Egyptians. Thus, they were referred to as foreigners by the three hill country sign for the foreign countries. This example represents the scarab of the $h k$ 3 $h 3 s t$ " $n t h r$ " "The foreign ruler ' $n t h r$, fig. (4) [5]. 


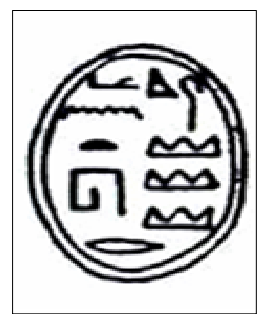

Figure (4) the scarab of the foreign ruler ' $n t$ hr (After Newberry, 1905, ancient Egyptian scarabs: An introduction to Egyptian seals and signet rings, London, pl. XXIII, no. 11)

\section{Gods Titles and Names Related to the hist Sign}

\subsection{The god spd $l \square \circlearrowright \triangle$ \\ The patron deity of the}

Twentieth Nome of Lower Egypt. His close connection with the desert led to his wide spread fame as the lord of the eastern desert which was near Asia that resulted in his description to bear the title of $n b$ h3swt "The lord (master) of the foreign countries" specially in the east, fig. $(5-a, b)[46]$.
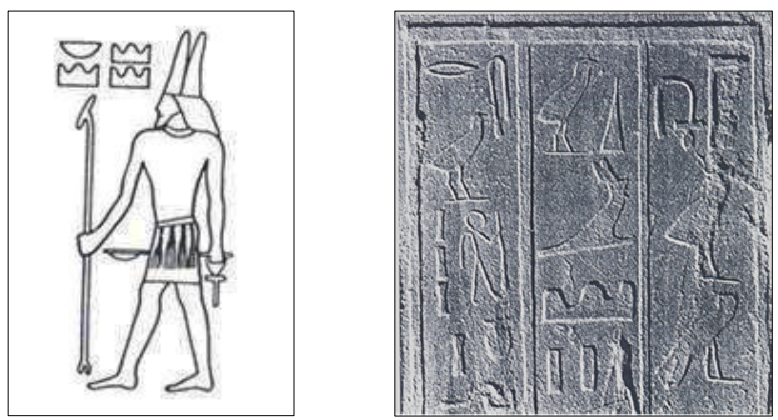

Figure (5) a God Spd as the lord of the foreign countries (After Lurker, 1995, an illustrated dictionary of the gods and symbols of ancient Egypt, London, p. 115) $\underline{\mathbf{b}}$ the name of the god Spd determined by the sign h3st inscribed in the temple of Hathor at Sinai (After Valbelle D. \& Bonnet, C., 1996, Le Sanctuaire d'Hathor Maitresse de la Turquoise, Paris, p. 38, fig. 50.

\subsection{The god $h 3$ 뚜}

Since the very beginning of the Egyptian Mythology, the God $h 3$ (the God of the Western Desert) was represented surmounted with an emblem composed of the three hill summits ( hist sign) symbol of the desert, fig. (6). As known, this crested mountain was regarded as the symbol of the desert in

association with the foreign countries and even the necropolis. The god was entitled as "The Lord of the West" and in sometimes $\{$ fo Ruler of the Temehu (Libyans) referring to the geographical position as westerners [47].

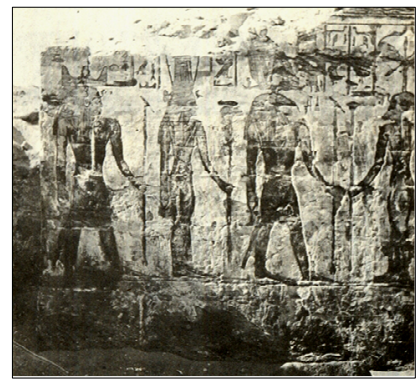

Figure (6) God $h 3$ of the deserts and the foreign lands with other gods at the Bahariya Oases (After Fakhry, 1974, the Oases of Egypt: Bahariya and Farafra Oases, Vol. II, Cairo, p. 86, fig. 25) 


\subsection{The god Min as a bull striking the sign $h 3 s t$}

The god Min was regarded as the god of the eastern foreign countries (where his cult centers were concentrated). So he became the god of the eastern desert and the lord of the foreign lands who had a permanent position in Nubia fig. (7).The adjectives of the god Min included his description as "The Bull who came from the foreign countries" so he was represented as a Bull with crescent-like horns crushing the sign $h 3 s t$ that symbolized the foreign countries [48].

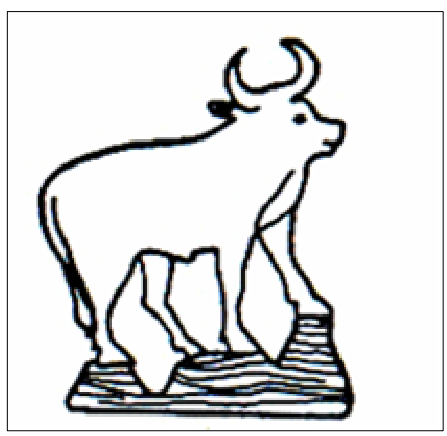

Figure (7) God Min in the form of a bull crushing the three hill country symbol of the foreign countries (After Petrie, F., 1939, the making of Egypt, New York, p. 64 pl. XXXIV)

\section{Conclusions}

-The sign h3st that was used in some of the ancient texts symbolizing the foreign countries was used as well to determine other significances such as the desert and the necropolis as both cases must have represented "The Outside" in the minds of the ancient Egyptians. The logic is - from the researcher's point of view - that the vast deserts are located outside the fertile Nile Valley. Besides, the Necropolis represented another world located outside their living boundary (as the realm of dead was usually on the western boundary of the Nile).

- Apart from the nature of the three hill country sign h3st, it was used as a determinative in the names of some Egyptian Nomes that is not bizarre as it determined either the desert or the mountainous regions in accordance with the significance of the sign.

\section{References}

[1] Baines, J. \& Malek, J., (2000). Cultural atlas of ancient Egypt, Andromeda Oxford Limited, Oxford.

[2] Adib, S., (2000). Mawsoat El-hadara El-maseria, Dar El-araby Lelnashr, Cairo.

[3] Betro M., (1996). Hieroglyphics: The writings of ancient Egypt, Abbeville Press, New York.

[4] Gardiner, A., (1978). Egyptian grammar, Oxford Univ. Press, London.

[5] Erman, A. \& Grapow, H., (1953). Wörterbuch der Ägyptischen sprache, Akademie-Verlag, LeipzigBerlin, $\mathrm{Vol}_{\mathrm{s}}$. I, II, III, IV\& V.

[6]Ward, W., (1982). Index of Egyptian administrative and religious titles of the Middle kingdom, The American Univ. of Beirut, Beirut.

[7] Gauthier, H., (1925-1931). Dictionnaire des noms geographiques contenus dans les textes Hieroglyphiques, L'Impri-merie de 1'Institut Francais d'Arch-eologie Orientale, Le Caire, Vol. I, II, IV, V \& VI

[8] Mohamed, A., (2010). Symbols of the foreign countries in the ancient Egyptian civilization: a linguistic archaeological and touristic study, MA, guidance dept., Faculty of Tourism and Hotels, Alexandria Univ., Egypt.

[9] Meeks, D., (1998). Anne Lexicographique Egypte ancienne, Tome I, Cybele Press, Paris. 
[10] Aman, M., (2008). Al-sahary almaseria wa athareha ala al-hayat wa el-mogtamaa al-masery al-kadeem men al-naheia al-ektsadia wa elseiaseya wa el-dineia hata nehayet asr al-dawla al-haditha, PhD, Egyptology dept., Faculty of archaeology, Cairo Univ., Egypt

[11] Goyon, G., (1957). Nouvelles inscriptions Rupestres du Wadi Hammamat, Imprimerie Nationale, Librairie d'Amerique et d'Orient Andrien-Maisonneuve, Paris.

[12] Faulkner, R., (1964). A concise dictionary of Middle Egyptian, Griffith Institute, Oxford.

[13] Saleh, A., (1962). Hadaret Maser al-kadima wa athareha, Matbaet El-hayeaa El-ama Leshoun Elmatabee El-amiria, Cairo.

[14] Badawi, A. \& Kees H., (1958). Handwörterbuch der Ägyptischen sprache, Staatsdruckerei, Ain Shames Univ., Kairo.

[15] Cerny, J., (1976). Coptic etymological dictionary, Cambridge Univ. Press, Cambridge.

[16] Pirelli, R., (2000). Two fragments of wall with inlaid decoration, The Treasures of the Egyptian Museum, The American Univ. in Cairo, Cairo.

[17] Shaw, I. \& Nicholson P., (2008). The illustrated dictionary of ancient Egypt, The American Univ. in Cairo, Cairo.

[18] Othman, E., (2006). Asmaa alamaken zat al-osool al-maseria: derasa laghaweia, tarekheia, seiaheia, MA, guidance dept., Faculty of Tourism and Hotels, Alexandria Univ., Egypt.

[19] Helck, H., (1984). Gaue, LA II, Otto Harrassowtiz, Wiesbaden-Germany.

[20] Hassan, S., (1944). Aksam maser al-goghrafeia fi al-aser al-feroni, Matbaet Lagunet El-taleef wa Altarguama wa Al-nashr, Cairo.

[21] Nor El-Deen, A., (2001). Al-logha al-maseria al-kadima, Dar ElFiker Al-arabi, Cairo.
[22] Ramzy, M., (1955). Al-kamous algoghrafy 11-elblad al-maseria, Division 2, Part 4, Al-hayeaa Almasreya Al-ama Lelketab, Cairo.

[23] Kamel, E. \& Abdel-Kader, M., (1985). Ikleem sharek el-delta fi osoreh al-tarekheia al-kadima, Part 2, Hayet Al-athar Al-masreya, Cairo.

[24] Abdel-Haleem, A., (1993). Algazera al-arabia wa manatekeha wa sokaneha fi al-nekoush al-kadima fi Maser: Al-baher al-ahmr wazaheroh fi al-osoor al-kadima, Ketab Bohouth Al-nadwa Alelmeya Al-oula Beguameat Alryad, Al-ryad, Saudi Arabia.

[25] Nor El-Deen, A., (2005). Mawakee wa matahef al-athar al-maseria, Dar Al-Maerefa Al-gamieia, Cairo., Egypt.

[26] Smolenski, M., (1938). Le nom geographique Vol. IX, p: 94

[27] Jones, D., (2000). An index of ancient Egyptian titles, epithets and phrases of the old kingdom, Vol. I, British Archeological Report, England.

[28] Ketshen, K., (1997). Ramsis althany: faraon al-maged wa alentsar, Al-alf ketab al-thany, alhayeaa al-maseria al-amaa llektab, Cairo., Egypt.

[29] Al-Mahdy, E., (2005). Ebadat wa mabodat Manf fi asr al-dawla alhaditha, PhD, Egyptology dept., Faculty of archaeology, Cairo Univ., Egypt

[30] Fakhry, A., (1938). Baharia and Farafra oases: A preliminary note on the new discoveries, ASAE, Vol. 38, pp: 397-434.

[31] Merzeban, R., (1997). Horizon in ancient Egyptian civilization (A linguistic, archeological, artistic and tourist study), MA, guidance dept., Faculty of tourism and hotels, Alex. Univ.

[32] Naville, E., (1886). Das Ägyptische todenbuch der XVIII bis XX dynastie, Vol. I, Chapter 17, Verlag von A. Asher \& Co., Berlin. 
[33] Sethe, K., (1909). Urkunden der 18 dynastie, $\mathrm{Vol}_{\mathrm{s}}$. I, \& IV, J.C Hinrichs' Buchhandlung, Leipzig.

[34] Abdel-Rahman, A., (2005). Ma'abad Der al-madina: derasa loghaweia denia, MA, Egyptology dept., Faculty of archaeology, Cairo Univ., Egypt

[35] Sethe, K., (1928). Ägyptische Lesestücke, J.C Hinrichs' Buchhandlung, Leipzig.

[36] Boraee, N., (2006). Mafhoom alkowa wa al-daef fi al-logha wa aldeiana al-maseria al- kadema hata nehaiet al-dawla al-haditha, MA, Egyptology dept., Faculty of archaeology, Cairo Univ., Egypt

[37] Gardiner, A., (1947). The ancient Egyptian onomastica, Vol. I, Oxford Univ. Press, Oxford.

[38] Newberry, P., (1912). The inscribed tombs of Ekhmim, AAA 4, Liverpool Univ. Press, London, pp: 99-120.

[39] Fischer, H., (1976). Notes, mostly textual on Davies' Deir El-Gabrawi, JARCE, Vol. 13, pp: 9-20.

[40] Faulkner, R., (1953). Egyptian military organization, JEA, Vol. 39, pp: $32-47$.

\section{Plate References'}

- Smith, W., (1949). A history of Egyptian sculpture and painting in the old kingdom, Oxford Univ. Press, London.

- Newberry, P., 1905, ancient Egyptian scarabs: An introduction to Egyptian seals and signet rings, Liverpool Univ. press, London.

- Lurker, M., (1995). An Illustrated dictionary of the gods and symbols of ancient Egypt, Thames \& Hudson Ltd., London.
[41] Newberry, P., (1893). Beni Hassan, Part 2, ASE 1, Egypt Exploration Fund, London.

[42] Aufrere, S., (2002). The deserts and the fifteenth and sixteenth Egyptian Nomes during the middle kingdom, Egypt and Nubia gifts of the desert, Liverpool Univ. Press, London.

[43] Smith, W., (1949). A history of Egyptian sculpture and painting in the old kingdom, Oxford Univ. Press, Oxford.

[44] Quibell, J., (1889). Hierakonpolis, Part II, B. Quaritch, London.

[45] Godron, G., (1968). A propos D'une inscription de Horus Khasekhem, CdE, Vol. XLIII, pp: 34-35.

[46] Giveon, R., (1984). Sopdu, LÄ V, Otto Harrassowtiz, Wiesbaden-Germany.

[47] Newberry, P., (1908). Two cults of the old kingdom, $A A A$ I, Liverpool Univ. Press, London, pp: 24-29.

[48] Mohamed, O., (2001). Al-thoor fi Maser al-kadima: derasa loghaweia-hadareia-seiaheia, MA, guidance dept., Faculty of tourism and hotels, Alex. Univ.

- Valbelle, S. \& Bonnet, C., (1996). Le Sanctuaire d'Hathor Maitresse de la turquoise, Acadmie des inscriptions \& belles-lettres, Paris

- Fakhry, A., (1974). The Oases of Egypt: Baharya and Farafra, oases, Vol. 2, American Univ. in Cairo press, Egypt

- Petrie, F., (1939). The making of Egypt, Sheldon press, NY. 